\title{
EFFECT OF STORAGE TEMPERATURE AND CULTIVARS ON SEED GERMINATION OF Lilium $\times$ formolongi HORT.
}

\section{Rameshwar Rai ${ }^{1,2}$, Jong Hwa Kim ${ }^{1,2 *}$}

${ }^{1}$ Department of Horticulture, Kangwon National University, Chuncheon 24341, Korea
${ }^{2}$ Oriental Bio-herb Research Institute, Kangwon National University, Chuncheon 24341, Korea

Received - August 05, 2020; Revision - September 04, 2020; Accepted - October 20, 2020

Available Online - October 25, 2020

DOI: http://dx.doi.org/10.18006/2020.8(5).621.627

\author{
KEYWORDS \\ Lilium $\times$ formolongi Hort. \\ Storage temperature \\ Seed germination \\ Coefficient of the velocity of \\ germination
}

\begin{abstract}
An experiment was carried out to evaluate the influences of seed storage temperature and variation due to cultivars on the germination of the Lilium $\times$ formolongi hort. seeds. The seeds of four cultivars of Lilium $\times$ formolongi Hort. viz. Augusta, Raizan Herald $(\mathrm{RH})$, Eorayeon 1ho, and Eorayeon 2 ho was treated with four temperature ranges $5^{\circ} \mathrm{C},-2^{\circ} \mathrm{C},-20^{\circ} \mathrm{C}$ and $20^{\circ} \mathrm{C}$ (Room temperature, Control) up to 6 months to execute the experiment. In total 500 seeds of each cultivar including four temperature regimes and four replications for each temperature treatment and each replication represented by 30 seeds have been provided 10 days chilling treatment before to test the germination to get the uniformity in germination. The laboratory experiment was carried out in a completely randomized design (CRD) to assess the different parameters of germination viz. germination percentage(GP), mean germination time (MGT), germination index (GI), time taken to 50\% germination (T50), and coefficient of the velocity of germination (CVG) at four temperature regime of four cultivars. The ANOVA analysis revealed significant variability among the four cultivars for all germination parameters in all temperature treatment levels. The results of the experiment demonstrated that the storage temperature has a great influence on germination percentage (GP), mean germination time (MGT), germination index (GI), time taken to 50\% germination (T50), and coefficient of the velocity of germination (CVG) with comparisons to the normal temperature stored seeds $\left(20^{\circ} \mathrm{C}\right)$. The significant variation among these parameters for each cultivar demonstrated the significance of varied requirements like stored temperature for the long term storage of that particular cultivar.
\end{abstract}

* Corresponding author

E-mail: jonghwa@kangwon.ac.kr (Jong-Hwa Kim); rairsansk@gmail.com (Rameshwar Rai)

Peer review under responsibility of Journal of Experimental Biology and Agricultural Sciences.

Production and Hosting by Horizon Publisher India [HPI] (http://www.horizonpublisherindia.in/).

All rights reserved.
All the articles published by Journal of Experimental Biology and Agricultural Sciences are licensed under a Creative Commons Attribution-NonCommercial 4.0 International License Based on a work at www.jebas.org.

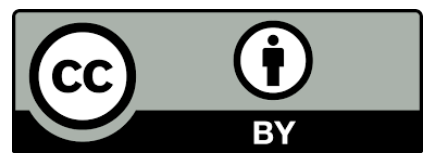




\section{Introduction}

Germination is the first and most important stage in the plant life cycle when the growth of a new plant begins from a seed. The germination process which starting from imbibitions, activation, and succeeding manifestation lasts for the plant life cycle. In this context, seed germination can be defined as one of the most important and first stages of the plant growth cycle which denotes protrusion of the radicle from the tissue enclosing it (Bewley \& Black, 2013; Baskin \& Baskin, 2014). In other broader aspects; seed germination is a complex physiological process regulated by genetic and environmental factors including temperature, water potential, oxygen, light, and ${ }_{\mathrm{P}} \mathrm{H}$ (Guo et al, 2020). Among the external factors affecting seed germination, the temperature is one of the primary important factors which play vital roles in affecting speed, rate, and percentage of germination (Marcos Filho, 2015).

The measurement of germination can provide valuable information about the percentage, rate, and time taken for germination of seeds, time taken for germination of $50 \%$ seeds, germination index, uniformity, and speed of germination. The germination rate provides the measure of the time course of seed germination. In other aspects, it is an estimate of the viability of seed or population of seeds. Another important aspect of seed germination is, of course, the rate of germination which is defined as the inverse of time to $50 \%$ germination (Bewley \& Black, 2013) and it is usually time courses taken for the germination rate of $50 \%$ of total seed population usually denoted by $\mathrm{T} 50$. The mean germination time (MGT) is another way to calculate germination speed and which is nowadays widely used by a broad range of seed scientists and other researchers related to plant biologists (Soltani \& Soltani, 2015). Likewise germination index and coefficient of the velocity of germination are other parameters deserving prime importance for the study of seed germination.

In east Asia especially in Japan and Korea, Lilium $\times$ formolongi Hort. is mainly seed propagated lily for cut flower production, seeds used to sow during winter (December to February) to get the flower in summer (July-August) (Ho et al., 2006, Xuan \& Kim, 2014). The seeds usually harvested in the months of late September to early October have to store 3-4 months before to sow in the plastic house to prepare for transplanting in the main field in and around the third week of April (Rai et al., 2018).To keep the seed vigor constant without deteriorating the seed quality and germination percentage is a challenging job for the lily grower farmers. To understand the better storage temperature of seeds of Lilium $\times$ formolongi Hort., it is necessary to investigate a wide range of temperature which demonstrate higher germination percentage and constant the other biological aspects of seeds. In Japan and Korea, this type of seed propagated lilies is grown on a relatively small scale (Anderson et al., 2012; Kang et al., 2013). For this purpose up facing longiflorum hybrids viz. Augusta F1,
Raizan herald is developed by Daicxhii Japan (Lim \& Van Tyul, 2007). Likewise, in Korea to fulfill the demand of seed market Eorayeon 1 ho and Eorayeon 2 ho were developed by KNU, a floricultural breeding laboratory(Xuan et al.,2009a; Xuan et al. 2009b). Seed propagated white trumpet lilies Lx formolongi Hort. were introduced for commercial cut flower production in the 1990s (Sato et al., 2010). Commercial Lx formolongi cultivars include Augusta F1, Raizan Herald (Sakigake Raizan)(Ho et al., 2006; Sato et al.,2010) while Eorayeon 1ho and Eorayeon 2ho were introduced in the first decade of the twenty-first century (Anderson et al., 2012). The objective of this experiment was to evaluate the effect of different temperatures on the seeds germination of four different cultivars of $L$. $\times$ formolongi Hort.

\section{Materials and Methods}

\subsection{Seeds materials and temperature treatment}

The seeds of four cultivars of Lilium $\times$ formolongi Hort. viz. Augusta, Raizen Herald, Eorayeon 1ho, and Eorayeon 2ho were stored at different temperatures viz. $-20^{\circ \mathrm{C}},-2^{\circ \mathrm{C}}, 5^{\circ \mathrm{C}}$, and $20^{\circ \mathrm{C}}$ (room temperature-Control) up to 6 months. After 6 months, treated seeds were surface sterilized with recommended fungicide Bhenoram @ $1 \mathrm{~g} / \mathrm{L}$ overnight separately covering the 500 seeds of each cultivar in gauze. This was followed by the inoculation of these sterilized seeds on the wet filter containing petri dish, each petri dish has 30 seeds and each treatment replicated four times. After keeping the seeds, all Petri dishes were well labeled with cultivars' names, treatments, and replication accordingly. Then Petri dishes were kept inside the chamber maintaining temperature $5^{\circ \mathrm{C}}$. After 10days of chilling treatment, observation on various germination parameters was recorded every day and with the help of forceps germinated seeds were discarded from the Petri dishes accordingly. After observation, distilled water was added over the tissue paper to maintain the moisture using the plastic bottle water sprayer.

\subsubsection{Germination percentage (GP)}

The germination percentage is a very usual term obtained by the number of germinated seeds divided by the total number of seeds and multiplied by 100 . After 10 days of chilling treatment, the number of germinated seeds of each cultivar and temperature treatment was recorded every after $24 \mathrm{~h}$ at morning 10 o'clock (AOSA, 1990). After 2 weeks of germination observation, the germination percentage was calculated by dividing the number of germinated seeds by the total number of seeds, multiplied by 100 (Tanveer et al., 2010; Cokkizgin \& Cokkizgain, 2010).

$$
\mathrm{GP}=\mathrm{S} / \mathrm{T} \times 100
$$

Where, GP=Germination percentage, $S=$ Number of germinated seeds, $T=$ Number of total seeds 


\subsubsection{Mean germination time (MGT)}

It is one of the common method or ways to calculate germination speed, in this, the mean germination time (MGT) was calculated adopting the formula as given by Ellis \& Roberts, 1980 as follows,

$$
\mathrm{MGT}=\sum(\mathrm{Dn}) / \sum \mathrm{n}
$$

Where $\mathrm{n}$ stands for the number of seeds germinated each day and $\mathrm{D}$ for the day of counting.

\subsubsection{Germination index (GI)}

It emphasizes both germination speed and germination percentage. The GI was calculated using the formula given by the Association of Official Seed Analysis (AOSA, 1983) as follows;

$$
\mathrm{GI}=\sum(\mathrm{GT} / \mathrm{Tt})
$$

\subsubsection{Time taken to $50 \%$ Germination (T50)}

The time to reach 50\% germination (T50) was estimated using the formula of Coolbear et al. (1984) and later on, modified by Farooq et al. (2005),

$$
\mathrm{T} 50=\mathrm{ti}+[(\mathrm{N} / 2-\mathrm{ni})(\mathrm{tj}-\mathrm{ti})] /(\mathrm{nj}-\mathrm{ni})
$$

Where $\mathrm{N}$ is the number of final germination count and ni, nj cumulative number of seeds germinated at adjacent days ti and $t j$ when $n i<\mathrm{N} / 2<\mathrm{nj})$

\subsubsection{Coefficient of the velocity of germination (CVG)}

The CVG indicates the rapidity of the germination of seeds. It increases when the number of germinated seeds increases and the time required for germination decreases. The CVG was estimated using the formula given by Maguire(1962) as,

$$
C V G=\frac{\left(G_{1}+G_{2}+\ldots+G_{n}\right)}{\left(1 \times G_{1}+G_{2}+\ldots+n \times G_{n}\right)}
$$

Where $G$ stands for the number of germinated seeds and $n$ stands for the last day of germination

\subsection{Statistical Analyses}

The raw data recorded were first arranged and prepared using MSExcel 2013. Then the estimation of all parameters related to germination as mentioned from 2.2 to 2.6 was performed following the formula accordingly. The replication wise calculated mean value of all parameters viz. Germination percentage (GP), Mean germination time (MGT), Germination index (GI), Time taken to $50 \%$ germination (T50), and Coefficient of the velocity of germination (CVG ) of each cultivar for different temperature treatment level viz. $20^{\circ}$ (normal temperature taken as control), $5^{\circ} \mathrm{C}$, $-2^{\circ} \mathrm{C}$ and $-20^{\circ} \mathrm{C}$ were used for the estimation of Analysis of Variance(ANOVA), F test adopting the TNAUSTAT- Statistical package (Manivannan,2014) for the completely randomized design(CRD). The Duncan's Multiple Range Test has been estimated at the $5 \%$ level of significance for the separation of estimated means of the treatments using the TNAUSTATStatistical package (Manivannan,2014)

\section{Results}

\subsection{Germination percentage (GP)}

The estimated germination percentage (GP) (Table 1) demonstrated that for the Augusta F1, the highest germination percentage $(95.8 \%)$ was recorded for the seed stored at $5^{\circ \mathrm{C}}$ while the lowest germination percentage $(7.5 \%)$ was recorded for seeds stored at $20^{\circ}$. Moreover, the remaining temperature treatment i.e. $-2^{\circ \mathrm{C}}$ and $-20^{\circ \mathrm{C}}$ seeds have also possessed more than $80 \%$ GP. The GP of seeds stored at $20^{\circ \mathrm{C}}$ was recorded lower besides Eorayeon 1ho that has possessed $80 \%$ GP. The GP of seeds stored both at $5^{\circ \mathrm{C}}$ and $-2^{\circ \mathrm{C}}$ were recorded more than $90 \%$ for all cultivars and more than $80 \%$ GP for seed stored at $-20^{\circ \mathrm{C}}$ for 3 cultivars besides Eorayeon 2 ho has possessed $75.8 \mathrm{GP}$.

\subsection{Mean Germination Time (MGT)}

In this experiment besides stored temperature, we have provided 10 days of chilling treatment of the seeds at $5^{\circ \mathrm{C}}$ then germination observation of the seeds was taken every day up to 2 weeks (14 days). The mean germination time (MGT) was found higher for the seed stored at $20^{\circ} \mathrm{C}$ (Control) ranging from 5.8 days(Eorayeon 1ho) to 12.4 days (Augusta)(Table 1). The temperature treatment of the seeds of all the four cultivars at $5^{\circ \mathrm{C}},-2^{\circ \mathrm{C}}$, and $-20^{\circ \mathrm{C}}$ has significantly decreased the MGT. The lowest MGT(2.4 days) were found for Raizan Herald seeds stored at $-20^{\circ \mathrm{C}}$ and thereby among their temperature treatment regime besides control highest MGT(5.5 days) were found for Augusta F1 seeds stored at $-2^{\circ \mathrm{C}}$. Among the four cultivars, Augusta F1 has demonstrated higher MGT for almost temperature range.

\subsection{Germination index (GI)}

It is one of the most comprehensive measurement parameters which comprises combining germination percentage and speed (spread, duration, and high/low events). The estimated GI (Table 1) demonstrated that normal temperature (control $20^{\circ} \mathrm{C}$ ) was found lower than other temperature treatments for all cultivars. The GI was found lower for the seed stored at $-2^{\circ} \mathrm{C}$ than the seeds stored at $5^{\circ} \mathrm{C}$ and $-20^{\circ} \mathrm{C}$ for all cultivars. Among these 3 temperatures treated seeds lowest GI was recorded for Augusta F1 (6.8) at $-2^{\circ \mathrm{C}}$ while the highest GI was recorded for Eorayeon $2 \mathrm{ho}(14.7)$ at $5^{\circ \mathrm{C}}$. 


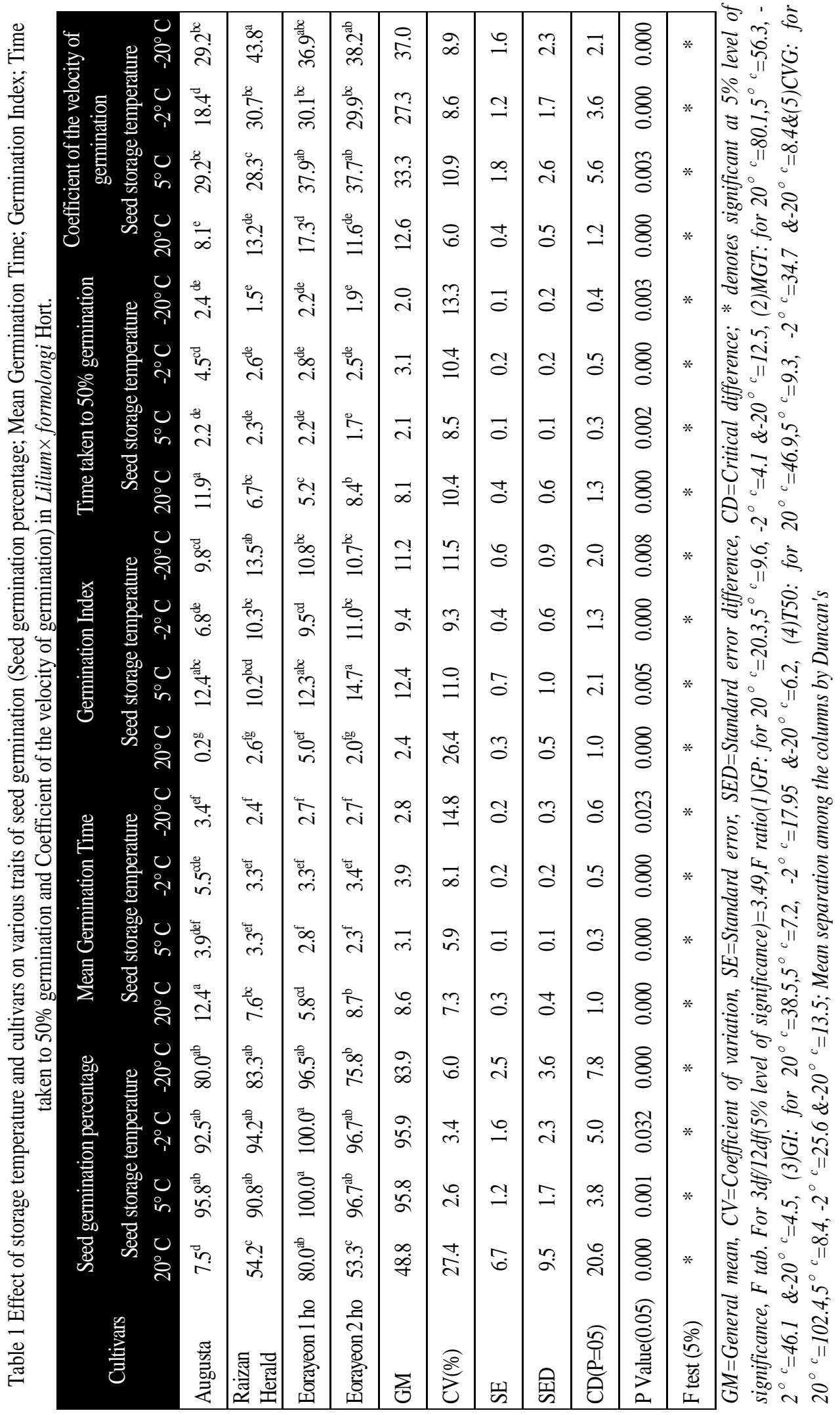

Journal of Experimental Biology and Agricultural Sciences http://www.jebas.org 


\subsection{Time taken to $50 \%$ germination (T50)}

The estimated times taken to $50 \%$ germination for all stored temperature of all four cultivars are given in Table 1. In comparison with room temperature $\left(20^{\circ} \mathrm{C}\right)$, the estimated time is taken to $50 \%$ germination (T50) for the stored temperature $5^{\circ} \mathrm{C}$, $2^{\circ} \mathrm{C}$ and $-20^{\circ} \mathrm{C}$ for all the cultivar under evaluation has been reduced significantly. T50 was recorded shortest for Raizan Herald (i.e.1.5 days) seeds stored at $-20^{\circ} \mathrm{C}$ while the longest $\mathrm{T} 50$ was recorded for Augusta seeds stored at normal temperature $\left(20^{\circ} \mathrm{C}\right)$. The seed of all cultivars stored in different temperature (i.e. $5^{\circ} \mathrm{C}$, $2{ }^{\circ} \mathrm{C}$, and $-20^{\circ} \mathrm{C}$ ) has demonstrated shorter T50 duration than the all cultivars seeds those stored at room temperature $\left(20^{\circ} \mathrm{C}\right)$ (Table 1) thereby indicating temperature treatment significantly decreasing the time taken for $50 \%$ germination (T50) for all four cultivars.

\subsection{Coefficient of the velocity of germination (CVG)}

The coefficient of the velocity of germination (CVG) demonstrated that temperature treatment has significantly increased the CVG of all cultivars. Among the various tested temperatures, the lowest $\mathrm{CVG}$ was reported at room temperature $\left(20^{\circ \mathrm{C}}\right)$ while other temperature treatment (i.e. $5^{\circ} \mathrm{C},-2^{\circ} \mathrm{C} \&-20^{\circ} \mathrm{C}$ ) demonstrated almost either 2 to 3 times higher $\mathrm{CVG}$ as compared to the room temperature (Control). Among three significant temperature treatments, the lowest CVG (18.4) was recorded for Augusta at$2^{\circ} \mathrm{C}$ while the highest CVG (43.8) was found for Raizan Herald at $-20^{\circ \mathrm{C}}$. Likewise, in comparisons with other cultivars, the CVG were found lower for Augusta for all stored temperature (Table 1).

\section{Discussion}

In this experiment, different aspects of seed germination viz. Germination percentage (GP), Mean germination time (MGT), Germination Index (GI), T50 (Time is taken for 50\% seed germination), and the coefficient of the velocity of germination were tested for the seeds of selected cultivars of $L$. $\times$ formolongi Hort. at different temperature viz. $20^{\circ} \mathrm{C}, 5^{\circ} \mathrm{C},-2^{\circ} \mathrm{C}$, and $-20^{\circ} \mathrm{C}$.

The temperature is one of the key environmental factors which influence the maximum germination rate and percentage of germination (Ketabi et al., 2016). Many researchers so far have been focused on the impact of temperature relating to the germination of the concerned crop species viz. Striga hermonthica (Del.) Benth. (Aflakpui et al., 1998), Lilium formosanum Wall. (Weng \& Hsu, 2006), Hosta yingeri SB Jones (Kim et al., 2015), Conanthera spp. (Tecophilaeaceae) (Cuadra et al., 2019) and Pinus bungeana Zucc. ex Endl. (Guo et al., 2020). Till now, the main concerns of the researchers are the impact of temperature on seed germination but the current study was not only focused on seed germination but also evaluate the effect of storage temperature on various genotypes of L.formolongi.
The germination percentage is one of the most important factors for the evaluation of seed quality and viability. The variation among the cultivars of $L \times$ formolong $i$ Hort for the same stored temperature of the seeds denoted the variation due to the genotype (Han \& Jia, 2008). On the other hand, the seed storage temperature has a great influence on the germination percentage which ranged from $6.5 \%$ to $100 \%$. The germination percentage also differs for the species of the crops (Roh \& Sim, 1996; Xiaoyu et al., 2003; Weng \& Hsu, 2006; Han \& Jia, 2008; Mascarello et al., 2011; He et al., 2011). Lee et al. (1999) evaluate the effect of priming on seed germination and concluded that there is no significant difference in the final germination percentage with primed seeds and control seeds in Lilium $\times$ formolongi.

The mean germination time is another important factor to be considered while testing the germination of seeds. In this experiment, the MGT has changed according to the cultivars and storage temperature. Such type of variation is very important for researchers to make decisions for the long term storage of seeds in a particular temperature with maintaining the seed quality and vigor for the future usages purpose (Kulshrestha et al., 2013).

Another most comprehensive measurement parameter that combines both GP and speed is the germination index (GI). According to Kader, (2005), GI is an analysis method which can describes both the GP/speed relationship and it is the most accurate as well. In this experiment, the seed is stored in different temperature treatment viz. $5^{\circ} \mathrm{C},-2^{\circ} \mathrm{C}$, and $-20^{\circ} \mathrm{C}$ had possessed higher GI than seed stored at normal temperature i.e. $20^{\circ} \mathrm{C}$ thereby signified the importance of temperature treatment to the seeds (Kader, 2005).

The coefficient of the velocity of germination $(\mathrm{CVG})$ is determined by the speed of seed germination in other words it indicates germination. According to Jones \& Sanders (1987), the CVG increases when the number of germinated seeds increases, and the time required for germination decreases. Theoretically, the highest CVG possible is 100 with a GI of one. It might achieve when all the seeds germinated on the first day (Jones \& Sanders, 1987). On the other hand, the coefficient of the velocity of germination (CVG) does not focus on the final percent of germination but emphasizes the time required for reaching it (Kader, 2005). We have achieved significantly higher $\mathrm{CVG}$ for temperature treated seeds i.e. seed stored at $5^{\circ} \mathrm{C},-2^{\circ} \mathrm{C}$, and $-20^{\circ} \mathrm{C}$ than seed stored at normal temperature $\left(20^{\circ} \mathrm{C}\right)$. Moreover, the $\mathrm{CVG}$ were found lower for Augusta than the other three cultivars for almost temperature treated seeds.

The temperature is important for maintaining seed vigor in other words temperature is responsible for the deterioration of flower seeds. The stored temperature of the seed deserves vital importance at each $5^{\circ \mathrm{C}}$ reduction in seed temperature doubles the life of the seed (Harrington, 1972). 
In this way, in this experiment different five parameters of germination test viz. germination percentage (GP), mean germination time (MGT), germination index (GI), time is taken to $50 \%$ germination (T50), and coefficient of the velocity of germination $(\mathrm{CVG})$ has been estimated of all four cultivars of $\mathrm{L} . \times$ formolongi Hort. The significant ANOVA analysis for all those parameters of germination of all four cultivars for all temperature treatment provided the validity of this experiment.

Among the four cultivars, lowest GP was found for the seeds stored at $20^{\circ} \mathrm{C}$ which ranges from $7.5 \%$ to $80 \%$ while for all stored temperature of seed viz. $5^{\circ} \mathrm{C},-2^{\circ} \mathrm{C}$, and $-20^{\circ} \mathrm{C}$ all cultivars have possessed $83.3 \%$ to $100 \%$ germination thereby signifies the importance of stored temperature of seed to get higher GP. We have observed the germination of the seeds up to 2 weeks, the mean germination time for four cultivars stored at normal temperature ranges from 5.8 days to 12.3 days which indicates taking longer duration than temperature treated seeds i.e. $5^{\circ} \mathrm{C}$, $2{ }^{\circ} \mathrm{C}$, and $-20^{\circ} \mathrm{C}$ which demonstrated shorter mean germination time ranging from 2.4 days to maximum 5.5 days. Similar types of results we have observed for other parameters viz.GI, T50, and $\mathrm{CVG}$, which demonstrated the significance of storage temperature than normal storage temperature.

In this way, the storage temperature has a great influence on germination percentage (GP), mean germination time (MGT), germination index (GI), time is taken to $50 \%$ germination (T50), and coefficient of the velocity of germination $(\mathrm{CVG})$ which varied for each cultivar of L. $\times$ formolongi Hort. For the long time storage of the seeds of these cultivars, we can prefer $5^{\circ} \mathrm{C},-2^{\circ} \mathrm{C}$, and $-20^{\circ} \mathrm{C}$ than normal room temperature i.e. $20^{\circ} \mathrm{C}$.

\section{Acknowledgement}

This experiment was carried out with the financial support of GSP (Golden Seed Project) of MAFRA (Ministry of Agriculture, Food, and Rural Affairs), Republic of Korea (Project No.213007-05-4 SBN10)

\section{Conflict of interest}

We all the authors hereby declare that there is no conflict of interest among us.

\section{References:}

Aflakpui GK, Gregory PJ, Froud-Williams RJ (1998) Effect of temperature on seed germination rate of Striga hermonthica (Del.) Benth. Crop Protection 17:129-133.

Anderson NO, Berghauer E, Harris D,JohnsonLönnroos J, Morey M (2012) Discovery of novel traits in seed propagated lilium: Nonvernalization requiring, day neutral, reflowering, frost tolerant, winter hardy Lx formolongi. I. Characterization. Characterization. Floriculture and Ornamental Biotechnology 6:63-72.

AOSA (Association of official Seed Analysis) (1983) Seed vigor testing handbook. Contribution no.32 to the Handbook on Seed Testing, Association of Official Seed Analysis, Springfield, IL, USA.

AOSA (Association of official Seed Analysis) (1990) Rules for testing seeds. Journal of Seed Technology 12:1-112

Baskin JM, Baskin CC (2014)What kind of seed dormancy might palms have? Seed Science Research 24:17.

Bewley JD, Black M (2013) Seeds: physiology of development and germination. Springer Science \& Business Media.

Cokkizgin A, Cokkizgin H (2010) Effects of lead ( $\mathrm{PbCl} 2)$ stress on germination of lentil (Lens culinaris Medic.) lines. African Journal of Biotechnology 9:8608-8612.

Coolbear P,Francis A,Grierson D (1984) The effect of low temperature pre-sowing treatment on the germination performance and membrane integrity of artificially aged tomato seeds. Journal of Experimental Botany 35:1609-1617.

Cuadra CDL, Vidal AK, Lagomarsino F, Peñaloza P, Mansur LM, Huenchuleo C (2019) Effect of temperature and scarification on seed germination of Conanthera spp. (Tecophilaeaceae). Chilean Journal of Agricultural Research 29:323-329.

Ellis RH, Roberts EH (1980) Improved equations for the prediction of seed longevity. Annals of Botany 45:13-30.

Farooq MSMA, Basra SMA, Saleem BA, Nafees M, Chishti SA (2005) Enhancement of tomato seed germination and seedling vigor by osmopriming. Pakistan Journal of Agricultural Sciences 42:3-4.

Guo C, Shen Y, Shi F (2020) Effect of Temperature, Light, and Storage Time on the Seed Germination of Pinus bungeana Zucc. ex Endl.: The Role of Seed-Covering Layers and Abscisic Acid Changes. Forests 11:300.

Han XL, Jia GX (2008) Studies on Optimal Germination Conditions of Different Cultivars and Heat-resistance Techniques for Seeds of Lilium $\times$ formolongi [J]. Forest Research 5.

Harrington JF (1972) Seed storage and longevity. Seed biology $3: 145-245$.

He ZM, Wen WX, Wang FL, Wang WT, Huang BH, Qiao ZQ, Zhou HG (2011) Study on seed germination of Lilium formolongi. Guangdong Agricultural Sciences 16. 
Ho CW, Jian WT, Lai HC (2006) Plant regeneration via somatic embryogenesis from suspension cell cultures of Lilium $\times$ formolongi Hort.using a bioreactor system. In Vitro Cellular \& Developmental Biology- Plant 42:240-246.

Jones KW, Sanders DC (1987) The influence of soaking pepper seed in water or potassium salt solutions on germination at three temperatures. Journal of Seed Technology 97-102.

Kader MA (2005) Comparison of seed germination calculation formulae and the associated interpretation of resulting data. Journal and Proceeding of the Royal Society of New South Wales 138:65-75.

Kang YI, Joung HY, Goo DH, Choi YJ, Choi MP, An HR, KO JY, Choi KJ, Lee KH, Hong KW (2013) A survey on cut flower cultivar trends and horticultural status of lilies(Lilium hybrids) in South Korea. Horticultural Technology 23:629-634.

Ketabi HZ, Khazaei HR, Nezami A, Aghdaei SRT (2016) Estimation of the cardinal temperatures for germination of four Satureja species growing in Iran. Herba Polonica 62:7-21.

Kim HJ, Choi SH, Kim YJ (2015) Effects of temperature on seed germination and photoperiod on seedling growth of Hosta yingeri SB Jones. The Horticulture Journal MI-104.

Kulshrestha V, Singh B, Meena SK, Dixit S (2013) Seed germination studies on Vicia faba L. under salt stress. Indian Research Journal of Gene Biotechnology 5:178-185.

Lee JW, Kim TJ, Kim JH, Kim HH, Lee CH, Choi KS, Paek KY (1999) Effect of priming on seed germination and seedling growth of Lilium formolongi. Horticultural Science \& Technology 17:136-137.

Lim KB, Van Tuyl JM (2007) Lily. Flower Breeding and Genetics 517-537.

Maguire JD (1962) Speed of germination-Aid in selection and evaluation for seedling emergence and vigor. Crop Science 2:176-177.

Manivannan N (2014) TNAUSTAT-Statistical Package. Retrieved from https://sites.google/site/tnaustat accessed on 05 October, 2020

Marcos Filho J (2015) Seed vigor testing: an overview of the past, present and future perspective. Scientia Agricola 72:363-374.
Mascarello C, Sacco E, Carasso V, Zappa E, Suffia G, Mariotti MG, Ruffoni B (2011) Evaluation of the seed germination of two protected species: Lilium pomponium L. and Lilium martagon L. Acta Horticulturae 900:385-391.

Rai R, Shrestha J, Kim JH (2018) Combining Ability and Gene Action Analysis of Quantitative Traits in Lilium× formolongi. Journal of Agricultural, Life and Environmental Sciences 30:131-143.

Roh MS, Sim Y (1996) Seed germination of Lilium x formolongi as influenced by temperature and plant growth regulatores. Acta Horticulturae 414 , International Symposium on the Genus Lilium414:243-250.

Sato T, Miyoshi K, Okazaki K (2010) Induction of 2n gametes and $4 \mathrm{n}$ embryo in Lilium (Lilium $\times$ formolongi hort.) by nitrous oxide gas treatment. Acta Horticulturae 855: 243-247.

Soltani E, Soltani A (2015) Meta-analysis of seed priming effects on seed germination, seedling emergence and crop yield: Iranian studies. International Journal of Plant Production 9:413-432.

Tanveer A, Rehman A, Javaid MM,Abbas RN, Sibtain M, Ahmad AUH, Aziz A (2010) Allelopathic potential of Euphorbia helioscopia L. against wheat (Triticum aestivum L.), chickpea (Cicer arietinum L.) and lentil (Lens culinaris Medic.). Turkish Journal of Agriculture and Forestry 34:75-81.

Weng JH, Hsu FH (2006) Variation of Germination Response to Temperature in Formosan Lily (Lilium formosanum Wall.) Collected from Different Latitudes and Elevations in Taiwan. Plant Production Science 9(3):281-286. DOI: 10.1626/pps.9.281.

Xiaoyu S, Liping Y, Haoye J,Qingjie Y (2003) Study on the germination of Lilium Callosum. Zhiwu Yanjiu 23:61-65.

Xuan Y, Kyung HY, Kim JH (2009a) Breeding of Lilium formolongi F1 hybrid 'Eorayeon 1ho' for cut flower. Journal of Korean Flower Research Society 17:324-327.

Xuan Y, Kyung HY, Kim JH (2009b) Breeding of Lilium formolongi F1 hybrid 'Eorayeon 2ho' for cut flower. Journal of Korean Flower Research Society 17:328-331.

Xuan YH, Kim JH (2014) Breeding of Lilium formolongi 'Baikryungilho'for summer seasoncultivation by bulb planting. Flower Research Journal 22:205-208. 